worthy successors to those published in earlier volumes of the "Collected Papers".

\section{Scientific Research into Road Safety}

Under the \&uspices of the European Productivity Agency of the Organization for European Economic Co-operation, an international meeting to discuss arrangements for co-operation in scientific rosearch into road safety will be held at the Road Research Laboratory, Langley Hall, Langley, Bucks, during July 12-15 inclusive. Sir William Glanville, director of road research, will preside. The provisional agenda includes discussion of the progress of, as well as the responsibility for, road-safety research in various countries, possible new researches, and the best means of making known the results of research, especially to other research workers, on an international basis. Delegates will be asked to considcr whether any new arrangements for closer collaboration are necessary. Delegates are expected to attend from Austria, Belgium, Denmark, France, Greece, Italy, the Notherlands, Norway, Spain, Sweden, Switzerland, tho United Kingdom and the United States; the United Kingdom delegation will include two representatives of the Medical Research Council.

\section{The Advisory Group for Aeronautical Research and Development}

The Advisory Group for Aoronautical Resoarch and Development of the North Atlantic Treaty Organization announces the following schedule of meetings for the socond half of 1960 : August 24-26, Combustion and Propulsion Panel on "Advanced Propulsion Techniques" (Pasadena); Septemker $8-12$, a seminar jointly sponsored by the Group and the Istituto Lombardo di Scienze e Lettere, "Propulsion for Astronautics" (Varenna) ; September 26October 1, Structures and Materials Panel, "Structures and Materials" (Athens); October 3-4, Fluid Dynamics Panel, "Industrial Uses of Wind Tunnels" (Istanbul) ; Octobor 3-4, Flight Mechanics Panel, "Manned Ballistics and Weapons Systems Testing" (Istanibul) ; October 3-8, Aerospace Medical Panel, "Clinicel Problems in Aviation Medicine" and "Space Flight Problems" (Istanbul); October 3-8, Avionies Panel, "Navigation" (Istanbul). The tenth general assembly of the Advisory Group for Aeronautical Research and Development will take place in Istanbul during October 6-7. Further information can be obtained from AGARD-NATO, 64 rue de Varenne, Paris VII ${ }^{\circ}$.

\section{Caroline Haslett Travel Awards for Women Engineers}

THE General Section of the Caroline Haslett Memorial Trust has awarded travelling exhibitions to two British women engineers to enable thom to study the training, employment and prospects of women engineers in the U.S.S.R. The awards, the first to be made by the General Section of the Trust, have been made to Miss L. S. Souter, who at present is head of the Magnetic Materials Section of the A.E.I. Research Laboratory at Harlow, and Miss IR. Winslode, who is senior sales engineer with Research and Control Instruments, Ltd.

The Electronic Engineering Association: Awards

UNDer joint organization by the Radio Industry Council (London) and the Electronic Engineering Association, the scheme for awarding annual premiums for articles on electronics now reaches its tenth year. Articles published during 1960 will be considered by the panel of judges early in the New Year, and six premiums of 25 guineas will be awarded. Further information can be obtained from the Electronic Engineering Association, 11 Green Street, London, W.1, to which also eligible articles should be submitted before the end of the year.

\section{U.S. Record of Published Books}

A NEW American Book Publishing Record is now being issued which collects all entries listed in tho Publishers' Weekly during the previous calendar month and arranged according to the Dewey Decimal Classification; a combined author and title index is included (Vol. 1, No. 2, for the month onding March I, 1960. Pp. 96. Subscription: 11 dollars for 12 monthly issues (U.S.A. 10 dollars). New York : R. R. Bowker Company, 1960). Books are defined as non-periodical publications of 49 pages or more, and books on all subjects are included as well as those printed abroad, but 'published' in the United States in the sense of being offered for sale there through a single designated agent.

\section{Bibliography of British Journals and Newspapers}

Mr. F'. Atkinson, of the Hampstead Public Library, has prepared an admirable bibliography covoring, as Mr. F. Williams points out in an introduction, every book of substance dealing with English newspapers and journalism during tho most expansive period in their history (Library Association. Special Subject List No. 32: The English Nowspaper since 1900. Pp. 31. London: Library Association, 1960). Nearly 400 entries are classified under a dozen headings, of which biography includes most (109), and no aspect of the Pross is loft uncovered.

\section{Cytology and Cell Culture Genetics of Man}

"A Symposium on Cytology and Cell Culture Genetics of Man" has been published by the Amer. $J$. Human Genetics with tho aid of funds from the National Institutes of Health, Public Health Service, U.S. Department of Health, Education and Welfare. Reprints may be obtained on request from $D r$. Gordon Allen, Building 10, Room 2N208, National Institutes of Health, Bethesda 14, Maryland. The symposium is 42 pages in length and contains the following papers, originally presented in Pennsylvania on September 2, 1959: "The Chromosome Complements of Human Somatic Cells", by E. H. Y. Chu ; "Human Cytogenetics: Its Present Place and Future Possibilities", by C. E. Ford; "Sexual Dimorphism in Interphase Nuclei", by M. L. Bar'?; "Some Systems for the Genetic Analysis of Mammalian Cells", by L. Sachs and M. Krim ; and "Coll Cultures for Human Genetic Studies", by M. Fraccaro.

\section{Royal Commission Awards for the Exhibition of 1851}

THe following awards for 1960 have been announced. Senior Studentships : B. Brummer (Imperial Colloge of Science and Tochnology), for research in physical chemistry at the Imperial College of Science and Technology; M. J. M. Leask (University of Oxford), for research in physics at Oxford; S. K. Malhotra (University of Oxford), for research in zoology at Oxford; D. J. Williams (University of Sheffield), for research in theoretical chemistry at Oxford. The Senior Studentships are of the value of 